\title{
Mass Spectrometric Study of Some Protonated and Lithiated 2,5-Disubstituted-1,3,4-Oxadiazoles
}

\author{
Rafał Frański, Krystian Eitner, and Grzegorz Schroeder \\ Faculty of Chemistry, Adam Mickiewicz University, Poznań, Poland
}

Oles P. Szwajka

Donetsk State University, Donetsk, Ukraine

\begin{abstract}
The mass spectrometric behavior of lithiated derivatives of 2,5-disubstituted-1,3,4-oxadiazoles has confirmed the skeletal rearrangement presented earlier for protonated derivatives. In the case of $[\mathrm{M}+\mathrm{H}]^{+}$ions the loss of isocyanic acid was observed and for $[\mathrm{M}+\mathrm{Li}]^{+}$ions the loss of lithium isocyanate occurred. On the other hand, benzoyl ions $[\mathrm{RCO}]^{+}$were formed from $[\mathrm{M}$ $+\mathrm{H}]^{+}$ions, but not from $\left[\mathrm{M}+\mathrm{Li}^{+}\right.$ions. Formation of benzoyl ions was in agreement with the differences between bond orders calculated for $[\mathrm{M}+\mathrm{H}]^{+}$ions and neutral molecules. From $[\mathrm{M}+\mathrm{Li}]^{+}$ions the $[\mathrm{RCNLi}]^{+}$fragment ions were formed, but the formation of $[\mathrm{RCNH}]^{+}$ fragment ions from $[\mathrm{M}+\mathrm{H}]^{+}$ions was not observed. This result can be explained on the basis of theoretically calculated stabilities of these fragment ions, since the calculated heats of formation of $[\mathrm{RCNLi}]^{+}$ions were found to be substantially lower than those of the respective $[\mathrm{RCNH}]^{+}$ions. (J Am Soc Mass Spectrom 2003, 14, 289-294) () 2003 American Society for Mass Spectrometry
\end{abstract}

$\mathrm{M}$ ass spectrometric decompositions of lithiated molecules are especially interesting, mainly from the point of view of the structural analysis of organic compounds and the interesting fragmentation pathways of $\left[\mathrm{M}+\mathrm{Li}^{+}\right.$ions. A number of compounds have been ionized by lithiation and the mass spectrometric fragmentation pathways of generated $[\mathrm{M}+\mathrm{Li}]^{+}$ions have been studied. Recently, mass spectrometric fragmentation of lithiated molecules has been reported for polysaccharides [1], nitrostyrenes [2], annoheptocins [3], nucleobases [4], fatty acids [5], valinomycin [6], lipids [7-9], iridoids [10], loganins [11], cerebrosides [12], ginsenosides [13], polyglycols [14] and ceramides [15].

Mass spectrometric fragmentation pathways of protonated 1,3,4-oxadiazoles $\left([\mathrm{M}+\mathrm{H}]^{+}\right.$ions) have been recently studied by chemical ionization (CI) [16], electrospray ionization (ESI) and liquid secondary ion mass spectrometry (LSIMS) [17]. In this paper the mass spectrometric fragmentation pathways of protonated 1,3,4-oxadiazoles (1-6, Scheme 1) are analyzed in more detail and compared with the fragmentation pathways observed for lithiated derivatives.

Published online February 27, 2003

Address reprint requests to Dr. R. Frański, Faculty of Chemistry, Adam Mickiewicz University, Grunwaldzka 6, 60-780 Poznań, Poland. E-mail: franski@main.amu.edu.pl
The $\mathrm{B} / \mathrm{E}$ linked scan mass spectra of metastable ions were recorded by using LSIMS as a method for ion generation. The isotope ${ }^{6} \mathrm{Li}$ was used in order to establish whether or not the fragment ions deriving from [M $+\mathrm{Li}^{+}$ions contained lithium.

1,3,4-Oxadiazoles are known to show various types of biological activity [18-22] and are used in modern electronics [23, 24].

\section{Experimental}

Compounds 1-6 were prepared according to the procedure described previously $[25,26]$.

The standard LSI mass spectra and B/E LSI mass spectra of metastable ions were obtained on an AMD 604 two sector mass spectrometer of the reverse $\mathrm{B} / \mathrm{E}$ geometry, made by AMD Intectra (Harpstedt, Germany). A CsI gun supplied the primary ion beam $\left(12 \mathrm{keV}, \mathrm{Cs}^{+}\right)$. The secondary ion beam was accelerated to $8 \mathrm{kV}$. The compounds were dissolved in NBA (3-nitrobenzyl alcohol, Aldrich). Lithium perchlorate was added in order to obtain the ion corresponding to the lithiated molecule of 1-6. The ${ }^{6} \mathrm{LiClO}_{4}$ was prepared from ${ }^{6} \mathrm{LiOH}$ (Aldrich, St. Louis, Missouri).

Semiempirical calculations were performed by using the Winmopac Version 2.0 package (Fujitsu Limited, Chiba, Japan). Geometry was carried out with the PM3 hamiltonian with precise key. 


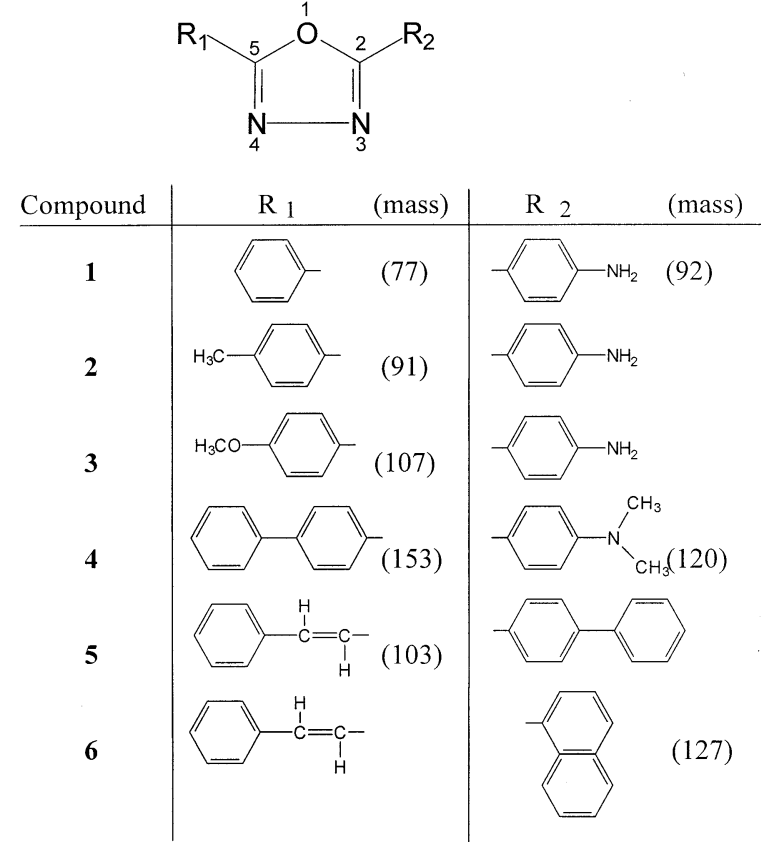

Scheme 1. Compounds studied.

\section{Results and Discussion}

As follows from a large body of evidence [1-15] mass spectrometric decomposition of protonated and lithiated molecules show some similarities and some differences. We compared the mass spectrometric fragmentation patterns of protonated and lithiated 2,5disubstituted-1,3,4-oxadiazoles. The standard LSI mass spectra of 2 with added $\mathrm{Li}^{+}$or ${ }^{6} \mathrm{Li}^{+}$are shown in Figure 1 as representative examples. High signals of protonated and lithiated molecules were always present in the standard LSI mass spectra. The B/E mass spectra of [M $+\mathrm{H}]^{+}$and $\left[\mathrm{M}+\mathrm{Li}^{+}\right.$ions were recorded.

The B/E mass spectra of protonated 1-6 molecules $\left([\mathrm{M}+\mathrm{H}]^{+}\right.$ions) are shown in Figure 2. In the previous paper the fragmentation pathways of protonated molecules of 2,5-disubstituted-1,3,4-oxadiazoles were presented [17]. It was shown that these compounds lost the isocyanic acid molecule (HNCO, loss of mass 43) from the oxadiazole ring. During mass spectrometric decomposition of the protonated Compounds 1-6, benzoyl ions $\left([\mathrm{RCO}]^{+}\right.$ions) were also formed.

In the case of lithiated derivatives the loss of lithium isocyanate molecules ( $\mathrm{LiNCO}$ ) occurred. The respective fragment ions were clearly seen in the $\mathrm{B} / \mathrm{E}$ mass spectra of $[\mathrm{M}+\mathrm{Li}]^{+}$and $\left[\mathrm{M}+{ }^{6} \mathrm{Li}\right]^{+}$ions as shown in Figures 3 and 4 . The respective product ions correspond to the loss of mass 49 for $[\mathrm{M}+\mathrm{Li}]^{+}$and 48 for $\left[\mathrm{M}+{ }^{6} \mathrm{Li}\right]^{+}$. However, formation of $[\mathrm{RCO}]^{+}$ions was not observed. Instead of $[\mathrm{RCO}]^{+}$ions, products ions rationalized as $[\mathrm{RCNLi}]^{+}$ions were observed.

There is a logical correlation between the fragmentation pattern of $[\mathrm{M}+\mathrm{H}]^{+}$and $\left[\mathrm{M}+\mathrm{Li}^{+}\right.$ions: if the $\left[\mathrm{R}_{\mathrm{n}} \mathrm{CO}\right]^{+}$ion is formed from the $[\mathrm{M}+\mathrm{H}]^{+}$ion, the $\left[\mathrm{R}_{\mathrm{n}} \mathrm{CNLi}\right]^{+}$ion is formed from the $[\mathrm{M}+\mathrm{Li}]^{+}$ion as
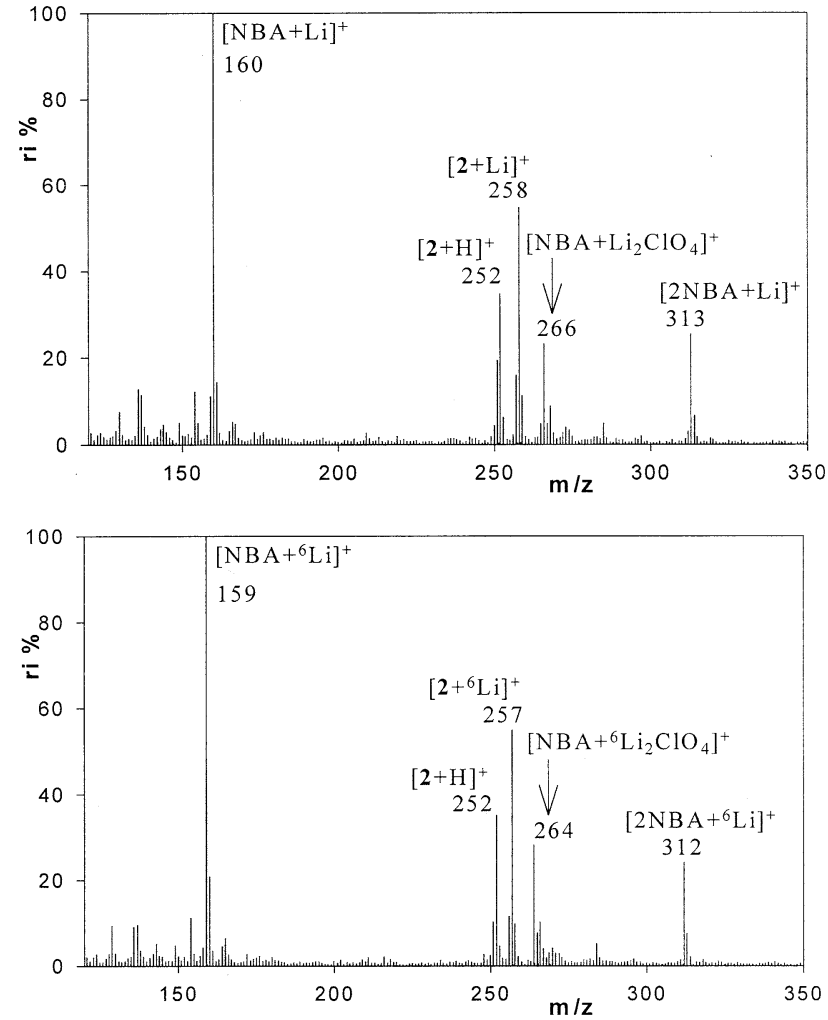

Figure 1. Standard LSI mass spectra of Compound 2 obtained with added $\mathrm{Li}$ and ${ }^{6} \mathrm{Li}$ cations.

shown in Figures 2-4. For example the $\left[\mathrm{H}_{2} \mathrm{~N}-\mathrm{C}_{6} \mathrm{H}_{4}-\mathrm{CO}\right]^{+}$ion $\left(\left[\mathrm{R}_{2} \mathrm{CO}\right]^{+}\right.$ion, $\left.m / z 120\right)$ is formed from the $[1+\mathrm{H}]^{+}$ion, the $\left[\mathrm{H}_{2} \mathrm{~N}-\mathrm{C}_{6} \mathrm{H}_{4}-\mathrm{CNLi}\right]^{+}$ion
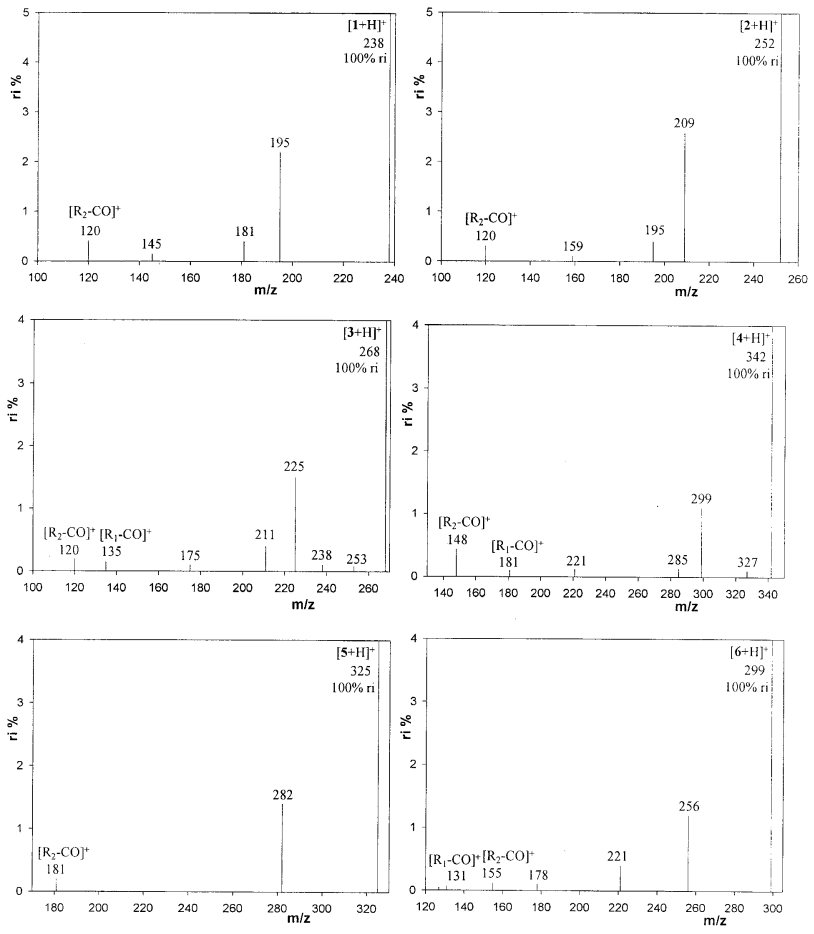

Figure 2. B/E mass spectra of $[\mathrm{M}+\mathrm{H}]^{+}$ions of Compounds 1-6. 

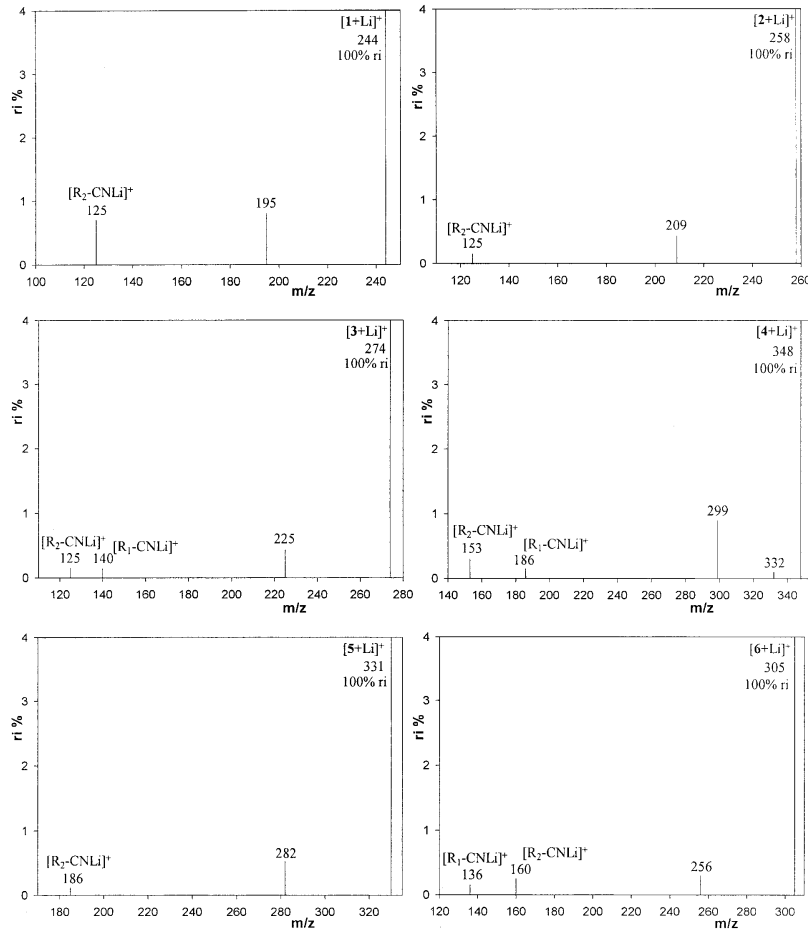

Figure 3. B/E mass spectra of $[\mathrm{M}+\mathrm{Li}]^{+}$ions of Compounds 1-6.

$\left(\left[\mathrm{R}_{2} \mathrm{CNLi}\right]^{+}\right.$ion, $m / z 125$ for $\mathrm{Li}$ and 124 for $\left.{ }^{6} \mathrm{Li}\right)$ is formed from the $[\mathrm{M}+\mathrm{Li}]^{+}$ion.

Theoretical calculations were performed in order to explain these phenomena. First, the most likely site of protonation or lithiation should be identified. The sites
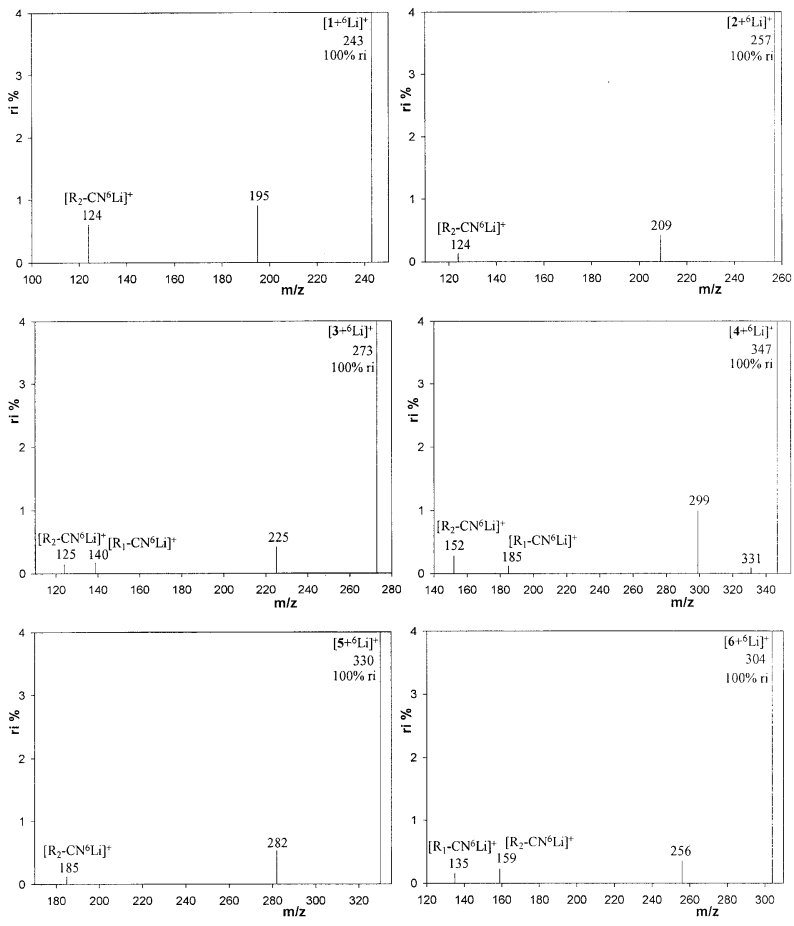

Figure 4. B/E mass spectra of $\left[\mathrm{M}+{ }^{6} \mathrm{Li}\right]^{+}$ions of Compounds 1-6. considered were the oxygen and two nitrogen atoms of the oxadiazole ring. The calculated heats of formation $\left(\Delta \mathrm{H}_{\mathrm{f}}^{\mathrm{o}}\right)$ of protonated 1-6 are shown in Table 1.

As Table 1 shows, the most stable protonated molecules are those with the proton attached to the $\mathrm{N}_{3}$ atom because the heats of formation of the molecules protonated at $\mathrm{N}_{4}$ atom are higher by about $5 \mathrm{~kJ} / \mathrm{mol}$ (differences are not large but reasonable). In the case of 3 , the probability of proton attachment to $\mathrm{N}_{3}$ or $\mathrm{N}_{4}$ is similar. Proton attachment to the $\mathrm{O}_{1}$ atom is unlikely. The calculations have shown that in this case, in Compounds 1-4, the oxadiazole ring fragments, leading to a structure very unstable relative to those protonated at nitrogen. In the case of $\mathbf{5}$ the calculation was not successfully completed.

As follows from Figure 2 and Table 1, the formation of $\left[\mathrm{R}_{2} \mathrm{CO}\right]^{+}$ions is favored over $\left[\mathrm{R}_{1} \mathrm{CO}\right]^{+}$ions. The $\left[\mathrm{R}_{2} \mathrm{CO}\right]^{22}$ ions contain the carbonyl carbon atom connected to the protonated nitrogen atom $\left(\mathrm{N}_{3}\right.$ atom). In other words, the formation of the $[\mathrm{RCO}]^{+}$ion seems to be dependent on the protonation site.

In the case of $[\mathrm{M}+\mathrm{Li}]^{+}$ions, the lithium cation appeared to be simultaneously connected to both nitrogen atoms of the oxadiazole ring by nearly equivalent bonds (Scheme 3) and this structure is favored over lithium attachment to the oxygen atom as shown in Table 2 .

The formation of $[\mathrm{RCO}]^{+}$from protonated molecules can be rationalized on the basis of the differences between the bond orders of the oxadiazole ring calculated for $[\mathrm{M}+\mathrm{H}]^{+}$ions and neutral molecules. The bond orders are shown in Scheme 2.

Formation of $\left[\mathrm{R}_{2} \mathrm{CO}\right]^{+}$from $[\mathrm{M}+\mathrm{H}]^{+}$ions required breaking the $\mathrm{C}_{2}-\mathrm{N}_{3}$ and $\mathrm{O}_{1}-\mathrm{C}_{5}$ bonds. In the case of [M $+\mathrm{H}^{+}$ions the calculated bond orders of the $\mathrm{C}_{2}-\mathrm{N}_{3}$ and $\mathrm{O}_{1}-\mathrm{C}_{5}$ bonds were lower (the bonds were weaker) than in the neutral molecules (Scheme 2). On the other hand the bond orders of the $\mathrm{O}_{1}-\mathrm{C}_{2}$ bonds were higher in the $[\mathrm{M}+\mathrm{H}]^{+}$ions (the bonds were stronger) than in the neutral molecules. Thus, the protonated molecules of 1-6 decomposed in such a way that the bonds of the lower order were cleaved, which is usually favored thermodynamically (requires less energy). The calculation of bond orders was also performed for $[\mathrm{M}+\mathrm{H}]^{+}$ ions with the proton situated at the $\mathrm{N}_{4}$ atom and analogous results were obtained. The $\mathrm{C}_{5}-\mathrm{N}_{4}$ and $\mathrm{O}_{1}-\mathrm{C}_{2}$ bonds were weakened and $\mathrm{O}_{1}-\mathrm{C}_{5}$ bonds were strengthened, which led to the formation of $\left[\mathrm{R}_{1} \mathrm{CO}\right]^{+}$ions. However, the formation of $\left[\mathrm{R}_{2} \mathrm{CO}\right]^{+}$ions was favored over the $\left[\mathrm{R}_{1} \mathrm{CO}\right]^{+}$ions. For example, in the case of 6 the $\left[\mathrm{R}_{2} \mathrm{CO}\right]^{+}$ion $\left(\left[\mathrm{C}_{10} \mathrm{H}_{7}-\mathrm{CO}\right]^{+}, m / z\right.$ 155) was more abundant than the $\left[\mathrm{R}_{1} \mathrm{CO}\right]^{+}$ion $\left(\left[\mathrm{C}_{6} \mathrm{H}_{4}-\mathrm{C}_{2} \mathrm{H}_{2}-\mathrm{CO}\right]^{+}, m / z\right.$ 131) as shown in Figure 2.

We recognize that bond energies should also be taken into consideration, however, it is difficult to determine which bonds are cleaved first and what are the structures of the neutral fragments eliminated on the formation of benzoyl ions. Therefore, the calculation of bond energies was not performed. 
Table 1. Heats of formation $\left(\Delta \mathrm{H}_{\mathrm{f}}^{\circ}\right)$ calculated for protonated Compounds 1-6

\begin{tabular}{lccr}
\hline Compound & $\begin{array}{c}\Delta \mathrm{H}_{\mathrm{f}}^{\circ} \text { for } \mathrm{O}_{1} \\
\text { protonated }(\mathrm{kJ} / \mathrm{mol})\end{array}$ & $\begin{array}{c}\Delta \mathrm{H}_{\mathrm{f}}^{\circ} \text { for } \mathrm{N}_{3} \\
\text { protonated }(\mathrm{kJ} / \mathrm{mol})\end{array}$ & $\begin{array}{c}\Delta \mathrm{H}_{\mathrm{f}}^{\circ} \text { for } \mathrm{N}_{4} \\
\text { protonated }(\mathrm{kJ} / \mathrm{mol})\end{array}$ \\
\hline \hline 1 & 950.7 & 904.0 & 911.5 \\
2 & 905.8 & 860.5 & 866.6 \\
3 & 781.5 & 736.4 & 737.0 \\
4 & 1032.9 & 993.6 & 999.5 \\
5 & - & 1071.7 & 1077.2 \\
6 & 1309.6 & 1061.6 & 1064.8 \\
\hline
\end{tabular}

We are aware that the differences in the calculated bond orders are not high but a correlation between the differences and fragmentation patterns of protonated 1-6 does not seem accidental.

The differences between bond orders of the oxadiazole ring calculated for $[\mathrm{M}+\mathrm{Li}]^{+}$ions and neutral molecules were not in good agreement with the fragmentation pattern of $[\mathrm{M}+\mathrm{Li}]^{+}$ions observed (Scheme 3).

The formation of $\left[\mathrm{R}_{2} \mathrm{CNLi}\right]^{+}$ions required breaking the $\mathrm{N}_{3}-\mathrm{N}_{4}$ and $\mathrm{O}_{1}-\mathrm{C}_{2}$ bonds and the formation of $\left[\mathrm{R}_{1} \mathrm{CNLi}\right]^{+}$ions required breaking the $\mathrm{N}_{3}-\mathrm{N}_{4}$ and $\mathrm{O}_{1}-\mathrm{C}_{5}$ bonds. Although the $\mathrm{N}_{3}-\mathrm{N}_{4}$ bonds were weakened by lithiation, the calculated bond orders of $\mathrm{O}_{1}-\mathrm{C}_{n}$ were nearly the same as in neutral molecules (Scheme 3). However, it was found that the $[\mathrm{RCNLi}]^{+}$ions were substantially more stable than respective $[\mathrm{RCNH}]^{+}$ions which were not formed from $[\mathrm{M}+\mathrm{H}]^{+}$ions. This result is presented in Table 3 where the calculated heats of formation of $\left[\mathrm{R}_{2} \mathrm{CNLi}\right]^{+}$and $\left[\mathrm{R}_{2} \mathrm{CNH}\right]^{+}$ions are compared.

The differences in the bond orders calculated for [M $+\mathrm{H}]^{+}$and $[\mathrm{M}+\mathrm{Li}]^{+}$ions are most likely related to the different structures of these ions, since the lithium is connected simultaneously to both nitrogen atoms $\left(\mathrm{N}_{3}\right.$ and $\mathrm{N}_{4}$ ).

It is more difficult to explain why the formation of $\left[\mathrm{R}_{2} \mathrm{CNLi}\right]^{+}$ions was favored over the $\left[\mathrm{R}_{1} \mathrm{CNLi}\right]^{+}$ions. For example, in the case of 6 the $\left[\mathrm{R}_{2} \mathrm{CNLi}\right]^{+}$ion $\left(\left[\mathrm{C}_{10} \mathrm{H}_{7}-\mathrm{CNLi}\right]^{+}, m / z\right.$ 160) was more abundant than $\left[\mathrm{R}_{1} \mathrm{CNLi}\right]^{+}\left(\left[\mathrm{C}_{6} \mathrm{H}_{4}-\mathrm{C}_{2} \mathrm{H}_{2}-\mathrm{CNLi}\right]^{+}, m / z 136\right)$ as shown in Figures 3 and 4 . The calculated bond orders of $\mathrm{N}_{3}-\mathrm{Li}$ bonds were always higher than in the case of $\mathrm{N}_{4}-\mathrm{Li}$ bonds, but the differences were only 0.01 (Scheme 3). However, it seems to be reasonable that lithium was

Table 2. Heats of formation $\left(\Delta \mathrm{H}_{\mathrm{f}}^{\mathrm{o}}\right)$ calculated for lithiated Compounds 1-6

\begin{tabular}{lrc}
\hline Compound & $\begin{array}{c}\Delta \mathrm{H}_{\mathrm{f}}^{\circ} \text { for } \mathrm{O}_{1} \\
\text { lithiated } \\
(\mathrm{kJ} / \mathrm{mol})\end{array}$ & $\begin{array}{r}\Delta \mathrm{H}_{\mathrm{f}}^{\circ} \text { for } \mathrm{N}_{3}-\mathrm{N}_{4} \\
\text { lithiated }(\mathrm{kJ} / \mathrm{mol})\end{array}$ \\
\hline \hline 1 & 895.6 & 787.9 \\
2 & 853.1 & 745.1 \\
3 & 733.5 & 628.4 \\
4 & 985.0 & 887.2 \\
5 & 1067.8 & 955.2 \\
6 & 1041.1 & 944.1 \\
\hline
\end{tabular}

more firmly bound to the $\mathrm{N}_{3}$ atom than to $\mathrm{N}_{4}$, as deduced for $[\mathrm{M}+\mathrm{H}]^{+}$ions (Table 1). This hypothesis can be confirmed by studies of the elimination of lithium isocyanate from an isotopic labeled compound, for example containing ${ }^{13} \mathrm{C}_{2}$ atom. For this compound, if the loss of $\mathrm{LiN}^{13} \mathrm{CO}$ (loss of mass 50 ) appears to be favored over loss of LiNCO (loss of mass 49), the
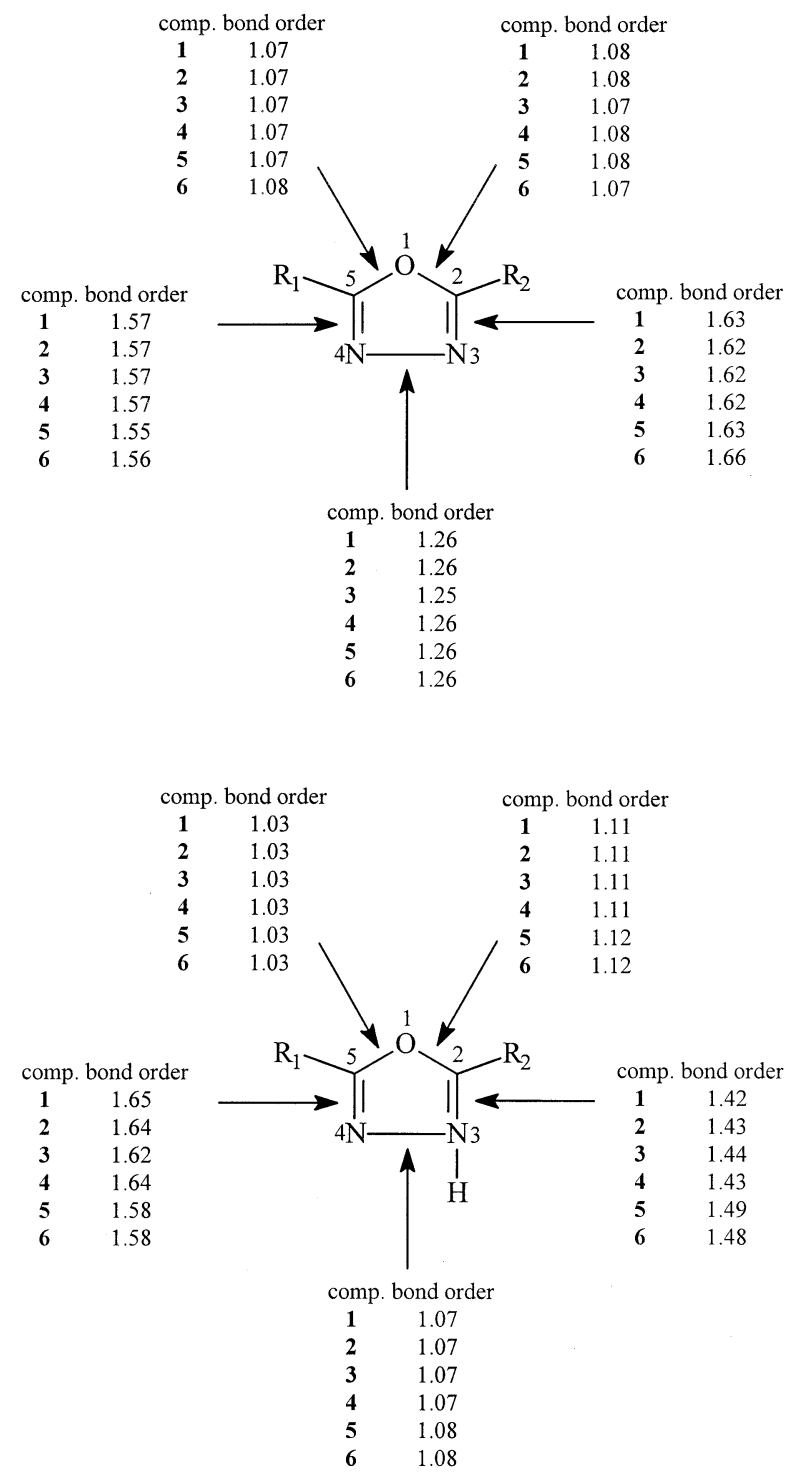

Scheme 2. The bond orders of oxadiazole ring calculated for neutral (top) and protonated (bottom) Compounds 1-6. 


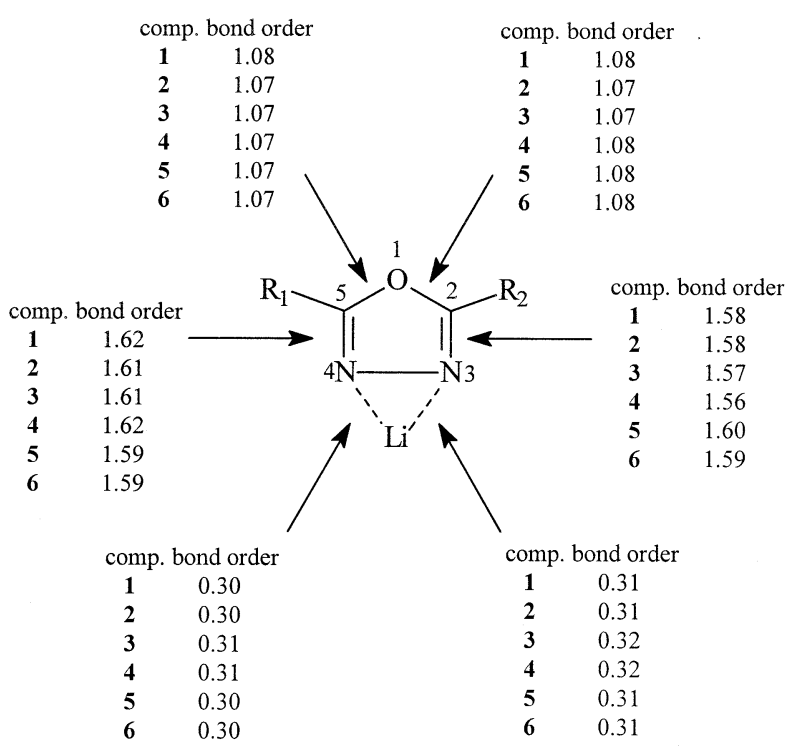

$\begin{array}{cc}\text { comp. bond order of } \mathrm{N}_{3}-\mathrm{N}_{4} \text { bond } \\ \mathbf{1} & 1.11 \\ \mathbf{2} & 1.10 \\ \mathbf{3} & 1.10 \\ \mathbf{4} & 1.10 \\ \mathbf{5} & 1.11 \\ \mathbf{6} & 1.11\end{array}$

Scheme 3. The bond orders of oxadiazole ring calculated for lithiated Compounds 1-6.

hypothesis will be confirmed. The preparation of this compound is in progress.

\section{Conclusion}

The mass spectrometric decomposition of lithiated and protonated 1,3,4-oxadiazoles revealed both similarities and differences. The decompositions consisting of skeletal rearrangement (loss of $\mathrm{HNCO}$ for $[\mathrm{M}+\mathrm{H}]^{+}$and $\mathrm{LiNCO}$ for $[\mathrm{M}+\mathrm{Li}]^{+}$ion) were observed in both cases. On the other hand, in the case of $\left[\mathrm{M}+\mathrm{Li}^{+}\right.$ions, the $[\mathrm{RCNLi}]^{+}$fragment ions were formed, but $[\mathrm{RCNH}]^{+}$ fragment ions were not formed from $[\mathrm{M}+\mathrm{H}]^{+}$ions. This phenomenon can be explained on the basis of the stabilities of $[\mathrm{RCNLi}]^{+}$and $[\mathrm{RCNH}]^{+}$ions, the former being more stable than the latter. Further, in the case of $[\mathrm{M}+\mathrm{H}]^{+}$ions, the $[\mathrm{RCO}]^{+}$ions were formed and this seems to be related to the variations in the bond orders as a consequence of the protonation site.

Table 3. Heats of formation $\left(\Delta \mathrm{H}_{\mathrm{f}}^{\circ}\right)$ calculated for $\left[\mathrm{R}_{2} \mathrm{CNLi}\right]^{+}$ and $\left[\mathrm{R}_{2} \mathrm{CNH}\right]^{+}$ions

\begin{tabular}{lcc}
\hline Compound & $\begin{array}{c}\Delta \mathrm{H}_{\mathrm{f}}{ }^{\circ} \text { for }\left[\mathrm{R}_{2} \mathrm{CNLi}\right]^{+} \\
(\mathrm{kJ} / \mathrm{mol})\end{array}$ & $\begin{array}{c}\Delta \mathrm{H}_{\mathrm{f}}{ }^{\circ} \text { for }\left[\mathrm{R}_{2} \mathrm{CNH}\right]^{+} \\
(\mathrm{kJ} / \mathrm{mol})\end{array}$ \\
\hline \hline $1-3$ & 745.1 & 917.4 \\
4 & 740.8 & 911.4 \\
5 & 857.3 & 1040.6 \\
6 & 836.3 & 1118.6 \\
\hline
\end{tabular}

\section{Acknowledgments}

The authors express their appreciation of discussions with Dr. B. Gierczyk.

\section{References}

1. Asam, M. R.; Glish, G. L. Tandem Mass Spectrometry of Alkali Cationized Polysaccharides in a Quadrupole Ion Trap. J. Am. Soc. Mass Spectrom. 1997, 8, 987-995.

2. Madhusudanan, K. P.; Bajpai, L. K.; Bhaduri, A. P. Effect on Lithium Cationization on Oxygen Atom Transfer from the Nitro Group to the Double Bond During Collision-Induced Decomposition in Certain Substituted $\beta$-Nitrostyrenes. Rapid Commun. Mass Spectrom. 1997, 11, 1263-1265.

3. Da Silva, E. L. M.; Roblot, F.; Hocquemiller, R.; Serani, L.; Laprévote, O. Structure Elucidation of Annoheptocins, Two New Heptahydroxylated $\mathrm{C}_{37}$ Acetogenins by High Energy Collision-Induced Dissociation Tandem Mass Spectrometry. Rapid Commun. Mass Spectrom. 1998, 12, 1936-1944.

4. Madhusudanan, K. P.; Katti, S. B. Elimination of Neutral Lithium Atom from Lithiated Nucleobases Upon CollisionInduced Decomposition. J. Mass Spectrom. 1998, 33, 20-24.

5. Hsu, F. F.; Turk, J. Distinction Among Isomeric Unsaturated Fatty Acids as Lithiated Adducts by Electrospray Ionization Mass Spectrometry Using Low Energy Collisionally Activated Dissociation on a Triple Stage Quadrupole Instrument. J. Am. Soc. Mass Spectrom. 1999, 10, 600-612.

6. Ngoka, L. C. M.; Gross, M. L. Multistep Collisionally Activated Decomposition in an Ion Trap for the Determination of the Amino Acid Sequence and Gas-Phase Ion Chemistry of Lithium-Coordinated Valinomycin. Int. J. Mass Spectrom. 2000, 194, 247-259.

7. Hsu, F. F.; Bohrer, A.; Turk, J. Formation of Lithiated Adducts of Glyceroposphoholine Lipids Facilitates Their Identification by Electrospray Ionization Tandem Mass Spectrometry. J. Am. Soc. Mass Spectrom. 1998, 9, 516-526.

8. Wang, W.; Liu, Z.; Ma, L.; Hao, C.; Liu, S.; Voinov, V. G.; Kalinovskaya, N. I. Electrospray Ionization Multiple-Stage Tandem Mass Spectrometric Analysis of Diglycosyldiacylglycerol Glycolipids from the Bacteria. Bacillus pumilus. Rapid Commun. Mass Spectrom. 1999, 12, 1189-1196.

9. Hsu, F. F.; Turk, J. Structural Determination of Glycosphingolipids as Lithiated Adducts by Electrospray Ionization Mass Spectrometry Using Low Energy Collision-Activated Dissociation on a Triple Stage Quadrupole Instrument. J. Am. Soc. Mass Spectrom. 2001, 12, 61-79.

10. Madhusudanan, K. P.; Mathad, V. T. Shefali; Raj, K.; Bhaduri, A. P. Characterization of Iridoids by Fast Atom Bombardment Mass Spectrometry Followed by CollisionInduced Dissociation of $[\mathrm{M}+\mathrm{Li}]^{+}$ions. J. Mass Spectrom. 2000, 35, 321-329.

11. Madhusudanan, K. P.; Raj, K.; Bhaduri, A. P. Effect of Metal Cationization on the Low Energy Collision-Induced Dissociation of Loganin, epi-Loganin, and Ketologanin Studied by Electrospray Ionization Tandem Mass Spectrometry. J. Mass Spectrom. 2000, 35, 901-911.

12. Hue, N.; Montagnac, A.; Pais, M.; Serani, L.; Laprévote, O. Structural Elucidation of Eighteen Cerebrosides from Holothuria coronopertusa in a Complex Mixture by High Energy Collision-Induced Dissociation of $[\mathrm{M}+\mathrm{Li}]^{+}$ions. Eur. J. Mass Spectrom. 2001, 7, 409-417.

13. Cui, M.; Song, F.; Liu, Z.; Liu, S. Metal Ion Adducts in the Structural Analysis of Ginsenosides by Electrospray Ionization with Multi-Stage Mass Spectrometry. Rapid Commun. Mass Spectrom. 2001, 15, 586-595. 
14. Chen, R.; Li, L. Lithium and Transition Metal Ions Enable Low Energy Collision-Induced Dissociation of Polyglycols in Electrospray Ionization Mass Spectrometry. J. Am. Soc. Mass Spectrom. 2001, 12, 832-839.

15. Hsu, F. F.; Turk, J.; Stewart, M. E.; Downing, D. T. Structural Studies on Ceramides as Lithiated Adducts by Low Energy Collision-Activated Dissociation Tandem Mass Spectrometry. J. Am. Soc. Mass Spectrom. 2002, 13, 680-695.

16. Seldes, A. M. D'; Accorso, N.; Souto, M. F.; Alho, M. M.; Arabehety, C. G. Gas-Phase Conversion of Tetrazoles to Oxadiazoles: Isolation and Acetylation of the N-Acylated Intermediate. J. Mass Spectrom. 2001, 36, 1069-1073.

17. Frański, R.; Schroeder, G.; Rybachenko, V.; Szwajka, O. P. Loss of Isocyanic Acid from the Internal Oxadiazole Ring of Protonated Molecules of Some 2,5-Diaryl-1,3,4-Oxadiazoles. Rapid Commun. Mass Spectrom. 2002, 16, 390-395.

18. Qiang, X.; Zhang, R. Synthesis and Insecticidal Activities of Novel 2,5-Disubstituted-1,3,4-Oxadiazoles. J. Chem. Technol. Biotechnol. 1996, 67, 124-130.

19. Rai, K. M. L.; Linganna, N. Synthesis and Evaluation of Antimitotic Activity of Alkylated 2-Amino-1,3,4-Oxadiazoles. II. Farmaco. 2000, 55, 389-392.

20. Liu, Z.; Yang, G.; Qin, X. Synthesis and Biological Activities of Novel Diheterocyclic Compounds Containing 1,2,4,-Tria- zolo[ $[1,5-\alpha]$ Pyrimidine and 1,3,4-Oxadiazole. J. Chem. Technol. Biotechnol. 2001, 76, 1154-1158.

21. Shi, W.; Qian, X.; Zhang, R.; Song, G. Synthesis and Quantitative Structure-Activity Relationships of New 2,5-Disubstituted-1,3,4-Oxadiazoles. J. Agri. Food Chem. 2001, 49, 124-130.

22. Chen, H.; Li, Z.; Han, Y. Synthesis and Fungicidal Activity Against Rhizoctonia solani of 2-Alkyl (Alkylthio)-5-Pyrazolyl1,3,4-Oxadiazoles (Thiadiazoles). J. Agri. Food Chem. 2000, 48, 5312-5315.

23. Belen'kii, L. I.; Luiksaar, S. I.; Poddubnyi, I. S.; Krayushkin, M. M. Novel Syntheses of Symmetrical 2,5-Diaryl-1,3,4-Oxadiazoles and 1,4-Phenylenebis-1,3,4-Oxadiazoles. Izv. Akad. Nauk Ser. Khim. 1998, 11, 2309-2315.

24. Janietz, S.; Anlaouf, S. A New Class of Organosoluble RigidRod Fully Aromatic Poly(1,3,4-Oxadiazole)s and Their Solid State Properties. 1. Synthesis. Macromol. Chem. Phys. 2002, 203, 427-432.

25. Grekov, A. P.; Szwajka, O. P. Synthesis of Some 2,5-Diphenyl1,3,4-Oxadizoles. Zh. Obshch. Khim 1960, 30, 3082-3086 (in Russian).

26. Szwajka, O. P.; Mnacakanova, T. P.; Golovatyi, V. G.; Schevchuk, L. G. Investigation of Oxadiazole Derivatives. Chem. Heter. Comp 1970, 2, 300-303 (in Russian). 